\title{
Laser Hemorrhoidoplasty in a Grade 3 Hemorrhoidal Disease: A Video Presentation
}

\section{Grade 3 Hemoroidal Hastalıkta Lazer Hemoroidoplasti Tedavisi: Video Sunum}

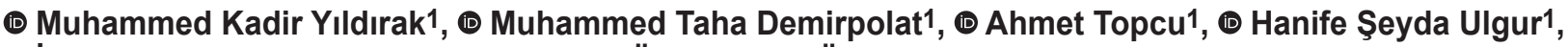 \\ ๑ I İlknur Turan1, ๑ Ayşe Duygu Kavas², ๑ Ömer Faruk Özkan1 \\ 1 University of Health Sciences Turkey, Ümraniye Training and Research Hospital, Clinic of General Surgery, İstanbul, Turkey \\ 2University of Health Sciences Turkey, Ümraniye Training and Research Hospital, Clinic of Anesthesiology and Reanimation, İstanbul, Turkey
}

\begin{abstract}
HIII\|II| ABSTRACT
Hemorrhoidal disease is a common perianal disease in the general population that negatively affects the quality of life. Treatment is indicated only if the patient is symptomatic. The disease stage is still determined according to Goligher's classification, and treatments are determined accordingly. At hemorrhoidal disease stages accompanied by prolapse, excisional surgery methods are preferred. However, the contemporary literature suggests that different treatment methods can be applied in symptomatic patients at earlier stages. These methods are stapled hemorrhoidopexy, Dopplerguided hemorrhoidal artery ligation and hemorrhoidopexy, rubber band ligation, and laser hemorrhoidoplasty. These procedures can be performed according to the surgeon's experience in appropriate patients within the indication. This video presentation demonstrates laser hemorrhoidoplasty treatment in a patient with grade 3 hemorrhoidal disease.
\end{abstract}

Keywords: Goligher's classification, hemorrhoidal disease, laser hemorrhoidoplasty

\section{|IIIIIIII| ÖZ}

Hemoroidal hastalık yaşam kalitesini olumsuz olarak etkileyen ve toplumda sık karşılaşılan perianal bölge hastalıklarındandır. Semptomatik olduğunda tedavi endikasyonu gelişir. Günümüzde halen kullanılagelen Goligher tarafından yapılan sınıflandırılmayla değerlendirilip tedavisi planlanmaktadır. Hemoroidal hastalığın prolapsusun da eşlik ettiği evrelerinde eksizyonel cerrahi yöntemleri ön planda olup daha erken evrelerdeki semptomatik hasta grubunda güncel literatür bir çok farklı tedavi yönteminin uygulanabileceğini önermektedir. Bu yöntemler stapler hemoroidopeksi, Doppler yardımlı hemoroidal arter ligasyonu ve hemoroidopeksi, lastik band ligasyonu ve lazer hemoroidoplasti olup endikasyon dahilinde uygun hastada cerrahın deneyimine göre yapılabilmektedir. Bu video prezentasyonda evre 3 hemoroidal hastalık nedeni ile lazer hemoroidoplasti uygulamasının sunulması amaçlanmıştır.

Anahtar Kelimeler: Goligher sinıflandırması, hemoroidal hastalık, lazer hemoroidoplasti

\section{Introduction}

Hemorrhoidal disease is the most common benign anorectal disease in the population. Its etiology is thought to be due to contractile mechanism damage in the corpus cavernosum recti. ${ }^{1}$ This damage is generally caused by an increase in intraabdominal pressure. Today, Goligher's classification is still used and planning is done according to this classification. A diet composed of fiber-rich foods, adequate fluid intake, and less straining during defecation comprises the basic approach to conservative treatment after classification. Oral flavonoids and suppositories, such as tribenoside, can be listed among the current medical treatments. At this stage, minimally invasive techniques without resection have been used instead of surgical resections in stage II-III hemorrhoidal disease that is unresponsive to treatment. These are rubber band ligation, infrared coagulation, Doppler-assisted hemorrhoidal artery ligation and hemorrhoidopexy, and 
laser hemorrhoidoplasty. ${ }^{2}$ The main advantage of these methods is that the postoperative pain is significantly less than with resection methods. This video presentation aims to show laser hemorrhoidoplasty application in a patient operated on for stage III hemorrhoidal disease.

Written informed consent was obtained and no preoperative preparation was made for the patient, except for preoperative 6-hour fasting. No prophylactic antibiotics or enemas were administered. The operation was conducted under general anesthesia in the gynecological dorsolithotomy position. The right anterior stage III hemorrhoid pack was tractioned. The probe was entered into the package by shooting with a laser (Neo V $1470 \mathrm{~nm}$ Diode) over the package, $2 \mathrm{~cm}$ proximal to the anal verge. The root of the hemorrhoid pack was reached, and the probe was removed after three shots proximally, two shots in the middle of the pack, and a single shot into the entrance hole. The operation was completed by applying wet gas compression and ice compression for one minute. The patient did not need analgesics except for standard paracetamol in the postoperative period and was discharged on the first postoperative day. Home rest was not recommended and they were encouraged to return to work with the recommendation of adequate fluid and fiber consumption.

As a result, we think that laser ablation of hemorrhoids is preferable for the hemorrhoidal disease at stage III or below due to the shorter operation time, less morbidity, and lower postoperative pain rates than conventional methods.
*This video presentation was recorded at the proctology course held at University of Health Sciences Turkey Ümraniye Training and Research Hospital on October 17, 2020.

\section{Ethics}

Informed Consent: Written informed consent was obtained and no preoperative preparation was made for the patient, except for preoperative 6-hour fasting.

Peer-review: Internally peer reviewed.

\section{Authorship Contributions}

Surgical and Medical Practices: A.D.K., Ö.F.Ö., Concept: Ö.F.Ö., M.K.Y., Design: M.K.Y., A.T., Data Collection or Processing: M.K.Y., A.T., H.Ş.U., Analysis or Interpretation: M.K.Y., M.T.D., İ.T., Literature Search: M.K.Y., M.T.D., İ.T., Writing: M.K.Y., M.T.D.

Conflict of Interest: No conflict of interest was declared by the authors.

Financial Disclosure: The authors declared that this study received no financial support.

\section{References}

1. Herold A, Lehur P, Matzel KE, O'Connell PR. Coloproctology. 2nd ed. Berlin, Germany: Springer. 2017:37-46.

2. Steele SR, Hull TL, Read TR, Saclarides TJ, Senagore AJ, Whitlow CB. The ASCRS Textbook of Colon and Rectal Surgery, 3th ed. Arlington Heights, IL, USA: Springer. 2016:183-203.

\section{Video 2.}

https://www.doi.org/10.4274/tjcd.galenos.2021.2020-10-13.video2 